\title{
Pharmaceutical feuds
}

\section{Charles Medawar}

Merck v. Glaxo: The Billion-Dollar Battle. By Matthew Lynn. Heinemann/Mandarin: 1991/1992. Pp. 244. £17.99 (Hbk)/ £5.99 (pbk).

The Aspirin Wars: Money, Medicine and 100 Years of Rampant Competition. By Charles C. Mann and Mark L. Plummer. Knopf: 1992. Pp. 420. \$25.

I HAVE only once picketed a pharmaceutical company - to protest about its roaring trade in appetite stimulants in developing countries. In the mid-1980s, the company dominated this unsavoury market with a range of products based on cyproheptadine, an antihistamine drug normally used to treat minor allergic conditions. Cyproheptadine can stimulate the appetite as a side effect, but it is not without risks; it is also expensive and makes no real contribution to health. In any case, it seemed indefensible to be selling appetite stimulants in countries where so many people were malnourished and starved.

The company said at the time that it had fully reviewed the situation and had concluded that appetite stimulation was a "well-established and medically valid" use of the drug. To others this signalled a marked lack of intellectual hygiene as well as bad taste - and it would seem natural to suspect that this said something about the culture of the company as a whole.

Matthew Lynn, however, has a great many nice things to say about Merck, and nothing at all critical. His is a journalist's description of a company that anyone could feel proud to work for; it is the biggest multinational drug company in the world and regarded by many as the best. Lynn represents the company as a first-rate institution, an honourable and excellent health-care provider that also performs outstandingly as a business. Indeed, he mentions twice that Merck Sharp \& Dohme has been voted the most admired corporation in the United States, although it is not made clear by whom.

Given this eulogy, it is surprising to find that Lynn represents Glaxo as just about everything that Merck would never want to be. Glaxo, he predicts, will go the way of Hoffman La Roche, the originators of Valium and other benzodiazepine tranquillizers. Lynn characterizes Roche as a flawed enterprise, a company crippled in the end by its own "poverty of ideals, humanity and humility". This is strong stuff and gives food for thought, although the reality is probably greyer than Lynn suggests. His jaundiced view of Glaxo seems barely more convincing than the rosy appreciation of Merck Sharp \& Dohme.
The author supports his essential proposition - Merck good, Glaxo not - mainly through a biography rounded off by an interview with Merck's man at the top. Roy Vagelos is characterized as "the philospher king", "one of the most brilliant American scientists of his generation", an outstanding manager and communicator who is "passionate about his commitment to corporate social responsibility". According to Lynn, his striving for honest dealing and better human values has left no part of Merck untouched. Vagelos himself says: "I do not have to worry that our people are out there describing our products in a way that I would not be proud of, in a way that I would not be proud to see on the front page of the New York Times".

By contrast, Sir Paul Girolami of Glaxo is represented as "dark and brooding", a brilliant but overbearing sales and numbers man. His company, it seems, is one in which morals count for rather less and where morale can dip quite low. Glaxo is depicted as secretive and opportunistic - not nearly as clever as Merck at inventing original and useful new drugs, although very sharp when it comes to selling and pricing them.

Lynn suggests that this explains the phenomenal success of Glaxo's anti-ulcer drug ranitidine: the promotion of " $\mathrm{Zan}$ tac" turned Glaxo from a sleepy and undistinguished concern into a company whose turnover now ranks second only to that of Merck Sharp \& Dohme. The gist of the story is that Glaxo used daring and cunning to establish Zantac at the top of the market, even though it was essentially an imitation of the original drug in this class, cimetidine or "Tagamet".

On therapeutic grounds, there would be little to choose between Zantac and Tagamet, yet Glaxo managed to see its rival off by persuading doctors and the public otherwise. The company took enormous financial risks by attempting to do the tests needed for licensing approval all at once, rather than in the usual strictly defined stages. In this way, Glaxo gained a lead of several years over its competitors. Then the company poured money into promotion, not least to contrast the well-established sideeffect profile of the older drug, Tagamet, with the virginal record of its own product. But its masterstroke was to pitch the price of Zantac high, an audacious ploy which helped to persuade doctors that Zantac really was the better product.

Battles of the Merck versus Glaxo kind differ from those over aspirin and the like. Drugs such as Zantac compete in monopoly markets, whereas the patents on aspirin have long since expired. So the competition between manufacturers of aspirin and other overthe-counter analgesics such as ibuprofen and paracetamol/acetaminophen, has traditionally centred on the sale of image rather than substance.

Unlike Lynn's book, which is an easy read, The Aspirin Wars gets off to a long

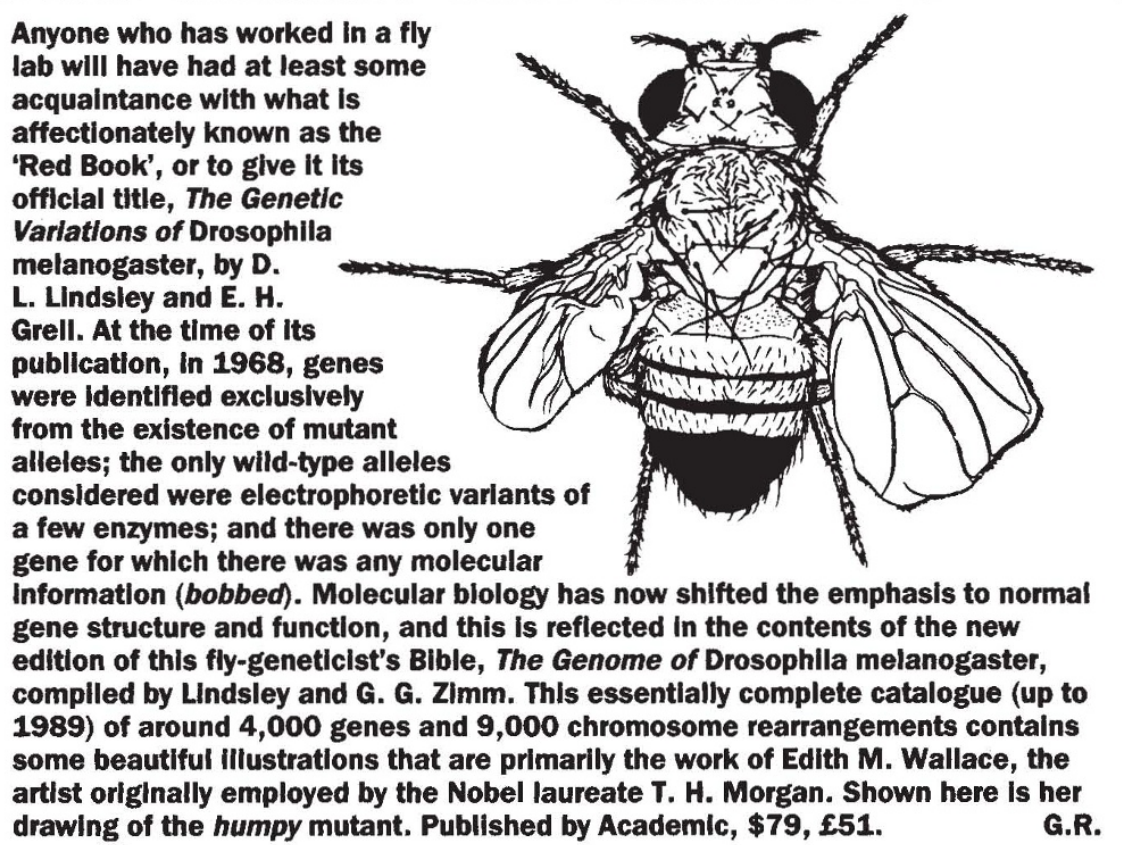

Anyone who has worked in a fly Alil have had at least some official title, The Genetic Varlations of Drosophila melanogaster, by $\mathrm{D}$.

L. Lindsley and E. H. Grell. At the time of its publication, in 1968, genes were Identifled exclusively from the existence of mutant alleles; the only wild-type alleles considered were electrophoretic varlants of a few enzymes; and there was only one Information (bobbed). Molecular blology has now shifted the emphasis to norma gene structure and function, and this is reflected in the contents of the new edition of this fly-geneticist's Bible, The Genome of Drosophlla melanogaster, complled by LIndsley and G. G. Zimm. This essentially complete catalogue (up to 1989) of around 4,000 genes and 9,000 chromosome rearrangements contains artist originally employed by the Nobel laureate T. H. Morgan. Shown here is her drawing of the humpy mutant. Published by Academic, $\$ 79, \mathbf{1 5 1}$.

G.R. 